\title{
New Realignment of Fears in France and Europe*
}

\author{
Nuevo realineamiento del miedo en Francia y en Europa
}

\author{
Dídac Gutiérrez-Peris \\ Viavoice París \\ didacgp@gmail.com
}

doi: http://dx.doi.org/10.18543/ced-59-2018pp99-114

\begin{abstract}
Contents: I. Introduction.-II. Growing support for authoritarian populist parties.-III. Low and falling trust in political institutions.-IV. Hardening of social attitudes on immigration and diversity.-V. French focus.-VI. A new triptych for French malaise.VII. Conclusions.-VIII. References.
\end{abstract}

\begin{abstract}
This article is based mostly on a study conducted throughout 2016 in France, Poland, the UK, Spain, Sweden and Germany with the think tank Demos and the Institute Notre Europe - Institut Jacques Delors, called 'Nothing to fear but fear itself'. The paper focuses mainly on France and departs from the statement that we are living a sort of backlash against the 'multiculturalist' approach to integration. This, as shown throughout the paper, cannot always be linked to some of the new fears European societies are facing, but it is the necessary contextual starting point when analysing one of those new fears, namely the hardening of social attitudes on immigration and diversity. This paper points out three of the most common symptoms regarding the new alignment of fears in Europe. It suggests that Europe is not only witnessing a rise of fearful attitudes about terrorism or uncertainty, but also the rise of a society that shows signs of exhaustion regarding the values that used to be the bed stone of European openness. The three symptoms described are: i) growing support for authoritarian populist parties, ii) a low and failing trust in political institutions, iii) a hardening of social attitudes regarding immigration and diversity.
\end{abstract}

Keywords: realignment of fears, European openness, integration, multicultural backlash.

Resumen: Este artículo está basado, principalmente, en un estudio realizado a lo largo del 2016 en Francia, Polonia, Reino Unido, España, Suecia y Alemania de la mano del think tank Demos y el Institute Notre Europe - Institut Jacques Delors, llamado "Nada que temer salvo el propio miedo". El artículo se centra, sobre todo, en el caso de Francia y parte de la afirmación de que estamos asistiendo

* Recibido el 10 de enero de 2018, aceptado el 9 de mayo de 2018. 
a una suerte de retroceso contra la aproximación 'multicultural' a la integración. Esto, como se plantea a lo largo del artículo, no siempre puede vincularse a algunos de los nuevos temores a los que las sociedades europeas se están enfrentando. Sin embargo, es el punto de partida contextual necesario para analizar uno de esos temores: el endurecimiento de las actitudes sociales en relación a la inmigración y la diversidad. El artículo apunta a tres de los síntomas más comunes respecto al nuevo alineamiento del miedo en Europa. Sugiere que Europa no sólo está asistiendo un incremento de actitudes temerosas hacia el terrorismo o la incertidumbre, sino también a una sociedad que comienza a mostrar signos de fatiga respecto de los valores que hasta ahora habían anclado la mentalidad abierta europea. Los tres síntomas que describe el artículo son: i) un apoyo creciente a partidos populistas autoritarios, ii) una confianza baja y decreciente en las instituciones políticas, iii) el endurecimiento de las actitudes sociales en relación a la inmigración y la diversidad.

Palabras clave: realineamiento del miedo, mentalidad abierta europea, integración, retroceso multicultural.

\section{Introduction ${ }^{1}$}

The topic of 'fear' in politics is a recurrent debate. The originality of some of the conclusions drawn in this note are based mostly on a study that we conducted throughout 2016 in France, Poland, the UK, Spain, Sweden and Germany with the think tank Demos and the Institute Notre Europe Institut Jacques Delors, called 'Nothing to fear but fear itself' 2 . This paper focuses mainly on France, since I was the main coordinator for the fieldwork in that particular country. The conclusions also mention some of the polling and research studies that we have published at Viavoice, a research institute focused on public opinion based in Paris. To all of them, thank you for letting me share some thoughts based on our collective work.

${ }^{1}$ This research note is based on the presentation given at Globernance, at the International Workshop on the European Crisis of Politics: Ethnoreligious Pluralism and the Rise of Radical Populism, Nativism and Far-right in Europe, which took place at the Museo San Telmo in San Sebastián in June 2017. This paper would not have been possible without Daniel Innerarity, Director of Globernance, as well as Cristina Astier and Ander Errasti, senior researchers at Globernance. I would like to start by thanking them for their invitation and for our regular research endeavours over the years. The reflections below benefited substantially from the contributions of Prof. Joxerramon Bengoetxea (University of the Basque Country), to whom I want to extend my sincere appreciation.

${ }^{2}$ Sophie Gaston, Nothing to Fear but Fear Itself, DEMOS (2017). 
I will start by saying that throughout 2016 and $2017-$ mostly before the French elections in June 2017-I have been evaluating the political context in Europe (and France) from the perspective of Jeffrey Alexander ${ }^{3}$, which claims we are living a sort of backlash against the 'multiculturalist' approach to integration.

This, as shown throughout the paper, cannot always be linked to some of the new fears European societies are facing, but it is the necessary contextual starting point when analysing one of those new fears, namely the hardening of social attitudes on immigration and diversity. One can easily recall some European leaders contributing or taking some inspiration from this backlash, such as David Cameron, for example, who called multiculturalism a 'dangerous' and 'wrong-headed doctrine' in $2008^{4}$. Similarly, some recent political discussion in Germany has used the term 'parallel societies' to speak about a presupposed 'divisive backlash' that has emerged during the last decade 5 .

Having in mind such context, this paper points out three of the most common symptoms regarding the new alignment of fears in Europe. It suggests that Europe is not only witnessing a rise of fearful attitudes about terrorism or uncertainty, but also the rise of a society that shows signs of exhaustion regarding the values that used to be the bed stone of European openness.

The three symptoms described are: i) growing support for authoritarian populist parties, ii) a low and failing trust in political institutions, iii) a hardening of social attitudes regarding immigration and diversity.

\section{Growing support for authoritarian populist parties}

A sign of the heightened sense of fear in European politics has been the emergence and electoral success of populist parties and policies promoting socially conservative, anti-EU and/or economically protectionist sentiments (see for example the extensive work conducted by Counterpoint, and in particular Marley Morris's analysis on 'reluctant radicals'6). On a more recent

3 Jeffrey Alexander, "Backlash Against Multiculturalism in Europe: Struggling Over the Mode of Incorporation". Conference organised by The Pears Institute for the Study of AntiSemitism, Birkbeck University of London (2013).

4 Andrew Sparrow in The Guardian (2008).

5 Sabine Ripperger in the Deutsche Welle (2012).

${ }^{6}$ Marley Morris, "The 'reluctant radicals' who offer conditional support to the far-right are key to understanding the success of right-wing populist parties in European elections", Blog entry at EUROPP, London School of Economics (2012). 
note, the EU membership referendum in the UK represents, in some aspects, a high watermark of this trend.

The difficulty between the rise of authoritarian populist parties in Europe is that they seem to be activating some of the voters and citizens who are broadly considered to be left behind. Researchers face, therefore, the challenge of examining this growing support for authoritarian parties without the pretence for criticising it. If, for example, the political community decides to follow the assumption that the ideal is to get more people engaged in politics, then it cannot be content with simply disapproving the political choices these disenfranchised citizens make-which in fact reflect a failure of mainstream parties and political institutions to present engaging narratives ${ }^{7}$.

On the other hand, to call this surge of populism as a sort of 'empowerment' underplays the heavily regressive and divisive aspects of such new politics. It also shows some political contradiction by voters - feeling disempowered and lacking control but voting for more authoritarian and less consensual political parties and leaders.

So it might be argued that even if this electoral trend seems clear, there is a debate about the eventual degree of empowerment it illustrates, if any.

\section{Low and falling trust in political institutions}

The cross-national polling conducted in 2017 (see reference 1) showed that there is - for some years now - very low levels of trust in both national and EU political institutions. For some countries, trust in national governments is higher than trust in the EU (particularly the United Kingdom), while for others the reverse is true (particularly, Poland and Spain)however, trust is low throughout.

The German research team presented for example evidence that German politicians and EU-level officials had failed to accurately diagnose the causes of low trust and EU-related concerns - focusing on the 'input legitimacy' of the EU (i.e., explaining what the EU is and does) rather than its 'output legitimacy' (how it addresses the specific concerns of citizens). In other words, there is too much emphasis on explaining how the EU works rather than fundamentally addressing why trust and engagement is so low.

There is, however, also the recognition that many of the reasons people reported dissatisfaction or lack of trust with the EU are in fact related to policy areas outside of the EU's competencies.

\footnotetext{
${ }^{7}$ Claudia Wood in The Guardian (2017).
} 
In this context, current mistrust and the 'you're either with us or against us' narrative is threatening to stifle free debate and side-lining the important contributions of 'experts' - now considered enemies of the state for their blind national optimism. Nowhere has this become more evident than in the aftermath of the Referendum on EU membership in the UK, where even fundamental institutions, such as the Bank of England and the Supreme Court, have been politicised to the extent that major daily newspapers have 'named and shamed' individual judges and called into question judicial independence.

In that sense, there are many examples showing the rise of this second symptom of 'fear politics' across Europe, yet we still have this 'original sin' in the case of the mistrust towards European institutions which is essentially the lack of understanding about who does what and how competences are distributed between the local, regional and European level. That particular topic is connected with the challenge of thinking about how to 'govern interdependence', a concept which is defined at length by a recent paper by Daniel Innerarity: "Transnational Self-determination. Resetting Self-Government in the Age of Interdependence"s.

\section{Hardening of social attitudes on immigration and diversity}

Finally, there is a transversal symptom linked with the hardening of social attitudes on immigration and diversity. Something that is not merely sociological, but political, as illustrated for example by the European Commission legal action in 2017 against Hungary, Poland and the Czech Republic for not accepting even one refugee despite the relocation engagement taken by those countries ${ }^{9}$.

From the Special Eurobarometer 437, 'Discrimination in the EU in 2015', we know for example that:

- Citizens in the EU are far less likely to feel comfortable working alongside a Muslim (71 per cent) than a Christian (94 per cent), atheist (87 per cent), Jew (84 per cent) or Buddhist (81 per cent). Similarly, just 50 per cent would feel comfortable if their son or daughter were in a relationship with a Muslim person, with 30 per cent saying they would be uncomfortable.

${ }^{8}$ Daniel Innerarity, "Transnational Self-determination. Resetting Self-Government in the Age of Interdependence", Journal of Common Market Studies, 53-5 (2015).

9 European Commission, "Progress under the European Agenda on Migration: Press conference by Commissioner Avramopoulos", Official documentation, Ref: SPEECH/17/1626 (2017). 
- 30 per cent of participants in the special Eurobarometer belonging to an ethnic minority group said they had experienced discrimination or harassment related to their ethnicity in the previous 12 months; 22 per cent of those from a religious minority said they had experienced discrimination or harassment on the grounds of their religion or beliefs.

This was partially reflected in our cross-national polling which found that in contrast to generally liberal attitudes around same sex relationships and the feminisation of the labour market, views tended to be more negative on the question of ethnic diversity and immigration. In France, Germany and Poland, in particular, a higher proportion of people felt greater ethnic and religious diversity had had a negative effect on their country than thought the reverse.

Particularly striking is a hardening of attitudes in countries that have traditionally held very liberal views on immigration. The Spanish research team, for instance, presented evidence that Spanish public opinion on immigration, which was once a liberal outlier compared to other European nations, has now moved into line with the EU average. Moreover, the Spanish case study found that $40 \%$ of Spaniards would vote for a party that pledged to reduce immigration.

In Poland, just before the election his party won in 2015, Jaroslaw Kaczynski accused refugees of 'bringing in all kinds of parasites' ${ }^{10}$. In June 2016, the country passed new anti-terrorism laws introducing measures such as the wiretapping of foreign citizens without a court order-one of the decisions that the European Commission has mentioned when launching for the first time ever its procedure to sanction the country under Article 7 of the Treaties ${ }^{11}$. In Hungary, since regaining the premiership in 2010, Prime Minister Viktor Orbán has been criticised for cracking down on media freedom and political accountability, as well as exploiting terrorist attacks in Europe to spread fear and promote Islamophobia and a narrow ethnic nationalism.

Even where populist parties have not formed governments, the politics of fear has asserted its influence on policy through restrictions on welfare and social security provision, driven in part by financial constraints, but also on a more politicised weakening of social bonds and solidarity. On a similar basis, a number of states have recently attempted to tighten eligibility rules for immigrants. This was at the forefront of David Cameron's

10 Jan Cienski, POLITICO (2015).

${ }^{11}$ European Commission, "Rule of Law: European Commission Acts to Defend Judicial Independence in Poland", Official documentation, Ref: IP/17/5367 (2017). 
EU membership renegotiation, which included an 'emergency brake' on in-work benefits for EU migrants. What is known in academia as welfare chauvinism towards migrants is part of a wider and much longer-running trend towards tightening general eligibility in many countries' welfare regimes.

In the UK, analysis of national newspapers by the Oxford Migration Observatory showed that the most common descriptor for the word 'immigrants' was 'illegal'. Other consistent terms found nearby in newspaper included those around legality and security ('terrorist', 'suspected', 'sham'), and those using water-based imagery ('flood', 'influx', 'wave') 12.

On the other side of the Channel, Hobeika and Villeneuve have studied for Counterpoint the topics of the Front National and the agenda of the French press: the articles containing "Islam" and "Muslim" show that journalists have a special interest in the topic when scandals related to Islam emerge outside the political world (for example, in the educational or cultural world.... $)^{13}$.

Finally, research has also shown that the prevalence of these narratives is not necessarily dependent on local realities. Donatella Bonansinga's research into attitudes towards Islam in the Czech Republic notes for example that Islamophobic sentiments are gathering momentum and rising quickly, although the country's Muslim population is 'tantamount to zero' 14 .

\section{French focus}

Throughout 2017, France embodied some of the trends observed above, though it has also provided an innovative case-study regarding the electoral effect of those rising fears. Unexpectedly, despite the combination of mistrust, hardening social attitudes regarding migrants and growing support for authoritarian populist parties, the political centre has been the main winner of the consecutive ballots for the Presidency and Parliament.

The French paradox is that despite being protected from major internal and external crises, it is still struggling to find a reassured state of mind within the new globalised world. The result is that the country is often slid-

12 The Migration Observatory, "A Decade of Immigration in the British Press", The Migration Observatory at the Oxford University (2016).

13 Alexandre Hobeika and Gaël Villeneuve, Les thèmes du Front National et l'agenda de la presse française (2006-2013), (Counterpoint, 2014).

${ }^{14}$ Donatella Bonansinga, "The Role of Public Discourse in Threat Framing: The Case of Islamophobia in Czech Republic”, CES Working Papers, 7-4 (2015). 
ing backwards into a negative, fearful and sometimes overcritical mentality about the future of the country.

This anxiety is the core feeling that is structuring the politics of fear in the country. The work of Franck Furedi, for instance, has pinpointed a subconscious and more profound origin of this specific mind-set which transcends particular periods of time ${ }^{15}$. Fear can be generated from manipulating the public opinion, but in France, it also exists as a force in its own right, as a 'fatalistic sensibility that coexists with anxieties concerning the future, which in turn disposes the public to feel uncomfortable about managing uncertainty' ${ }^{16}$. In such a context, fear has become synonymous with disagreement in modern political discourse, when in fact it could be analysed as a symptom of exhaustion, disengagement and, more importantly, uncertainty and insecurity about the future.

In a new best-seller published in September 2016 with a self-explanatory title (Pathologies Françaises), Alain Duhamel updates this thesis and explores the idea that it is precisely this notion of France - this dual historical framing theory - that seems to have enclosed the whole country in its own past and memory: France as a country being held prisoner of its own narrative. As Duhamel puts it, 'there is a heavy political and historical burden for a country that is failing to find a way to reframe a new vision for its people' ${ }^{17}$.

In that respect, this same 'Duhamelian' problem could be applied to the European continent as a whole. What we call 'fear' in Europe could therefore be analysed as the consequence of being trapped in an existential fear. Or in other words, the exhaustion of its own self.

In such a specific French context, the situation is complemented by new challenges in terms of mistrust within society.

First, as a reaction to the terrorist attacks that have spanned 15 months since 2017: Charlie Hebdo, l'Hyper Cacher, le Bataclan, le Stade de France, Magnanville, Nice, Saint-Étienne-Du-Rouvray...Those attacks have had two immediate effects regarding public opinion and the general social mood. First, support for new anti-terrorist measures: France is still under the 'état d'urgence', after renewing this exceptional legal framework four times. Interestingly, 3 of every 4 French citizens support the state of emergency ${ }^{18}$. And second, issues relating to insecurity and terrorism have been the first preoccupation of the population for many months now ${ }^{19}$.

\footnotetext{
15 Frank Furedi, Politics of Fear (London: Continuum, 2005): 123-24.

16 Ibid.

17 Alain Duhamel, Pathologies Françaises (Plon, 2016).

18 Boudet Alexandre, Huffington Post - YouGov (2016).

19 Europe (2016).
} 
Second, we are witnessing fear linked with economic and social uncertainty after several years of crisis, particularly among the youngest population and the oldest people in the workforce. A situation illustrated both by the OECD and the INSEE - the main statistical body in the country, showing that unemployment among young people (18-24) has increased in the last 5 years, up to $25 \%$. Concerning unemployment among people over 50 years, there is an increase of two points, from 5\% to $7 \%$.

Finally, we are witnessing a transfiguration of the political panorama, with the progressive consolidation of the Front National, in particular in the last 5 years, marked at the same time by a very unpopular socialist government and internal turmoil on the Conservative side after the Sarkozy years. In that sense, as mentioned earlier, the realignment of fears cannot be understood without the crisis of mainstream political forces.

\section{A new triptych for French malaise}

Such a new 'triptych' could be summarised as follows:

a) The French malaise that emerged abruptly in 2005 with the negative vote on the European Constitution regarding globalisation has not faded away. French are the most negative compared to the other European case-studies when judging the impact of globalisation for their country. But more importantly, they express a qualitative difference between the different items tested. The negativity regarding the impact for 'France' is the only item where we have more negative opinions than positive ones.

In other words, globalisation is generally perceived as positive for Europe, for oneself and for regions, but not for the country, reinforcing the notion of 'déclassement national'. As if globalisation was, per se, incompatible with the idea of France itself (fig.1 and 2). 


\section{'French malaise'}

\section{GLOBALISATION (Europe)}

"Over recent decades the world has become more interconnected. There is greater free trade between countries and easier communication across the globe. Money, people, cultures, jobs and industries all move more easily between countries. Generally speaking, do you think this has had a positive or negative effect on... »

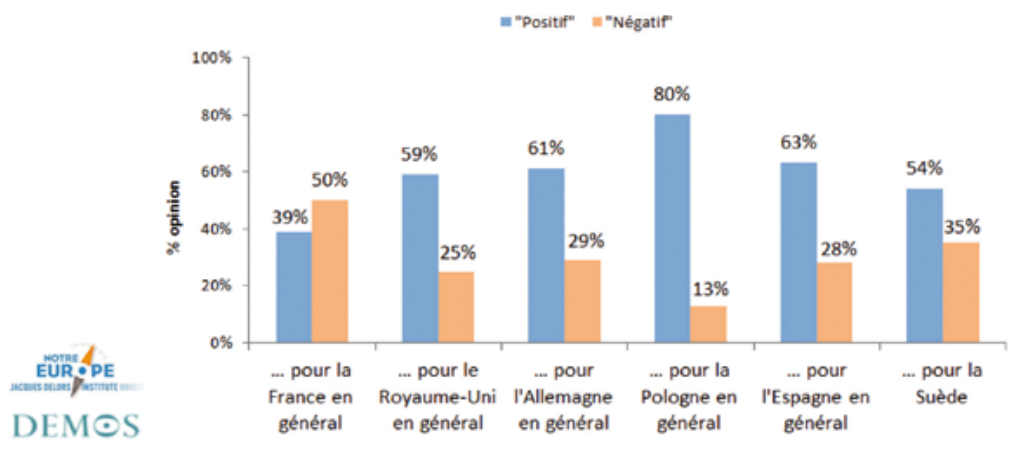

Figure 1

\section{'French malaise'}

\section{GLOBALISATION (France)}

"Over recent decades the world has become more interconnected. There is greater free trade between countries and easier communication across the globe. Money, people, cultures, jobs and industries all move more easily between countries. Generally speaking, do you think this has had a positive or negative effect on..."

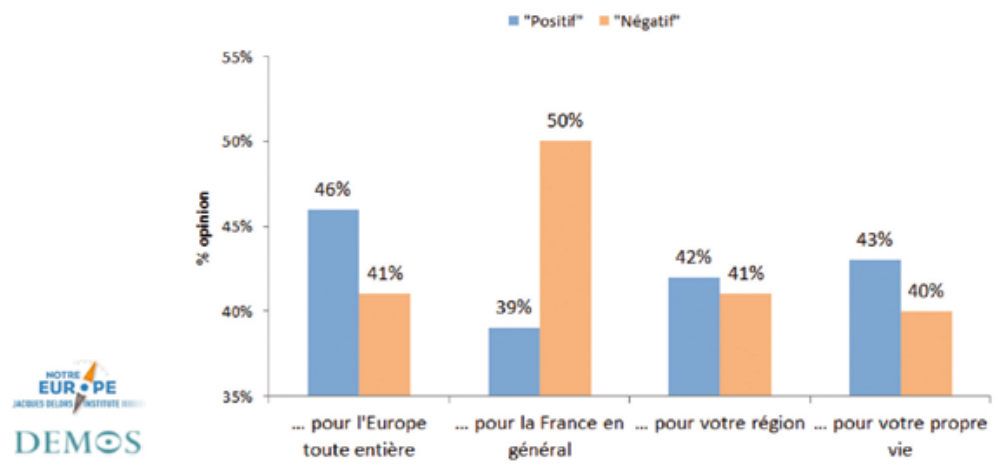

Figure 2

Cuadernos Europeos de Deusto 
b) Beyond the diversity of factors, the downfall of the French (and European) political class

The French are, globally, more critical when answering to a survey (this is one of the classical insights that comparative survey marketing has showed us) but still, they remain the most critical of all Europeans regarding their political institutions, with striking levels. A key learning of the Demos survey is that they are equally critical to all institutions, irrespective of the geographical level (usually European institutions have a better degree of trust than national institutions) - for example, the last Eurobarometer ( $\mathrm{n} .{ }^{\circ}$ 85) still gives a slight advantage to the European Commission in terms of trust (33\% of average European citizens trust the European Commission, while only $28 \%$ of average citizens trust their national Parliament).

In that sense, the last decade marked by the financial crisis has had an impact regarding the image of European Institutions: in comparison, in 2007, one of every two Europeans trusted the European Commission, while only one in three trusted their national Parliament. After the crisis, this advantage has disappeared.

c) Third and final finding: this isn't over yet

Finally, the conducted survey included some questions phrased as 'predictions', as a way to test public perception regarding the probability of some major events connected with current social, economic, and security uncertainty. In other words, some of the questions were drafted as an invitation to the respondent to 'bet' on what's next for France. We tested three of the crises that have struck Europe over the last few years and that are supposed to have been addressed by policy-makers. As with the rest of the fieldwork, the questions were posed to a representative sample of 1000 citizens using the method of quotas. As a reminder, the fieldwork was administrated in September 2016.

Surprisingly, respondents seemed resigned to face the repetition of certain events:

i) 8 people out of ten think that a terrorist attack is probably going to happen in the next six months. This is crucial because it confirms the idea that the state of mind of French people is highly influenced by the fear of an attack (fig. 3).

ii) 7 people out of ten think that a major financial crisis is coming. This is particularly interesting because it allows us to point out that all the policies undertaken at the European level to solve the crises have, probably, not been perceived by the population (Banking Union, Stability Pact, rescue plans, European Stability Mechanism...). (fig. 4) 
A never-ending crisis?

\section{TERRORISM}

"How likely or unlikely do you think the following things are to happen in France? Another major terrorist attack in the next six months "

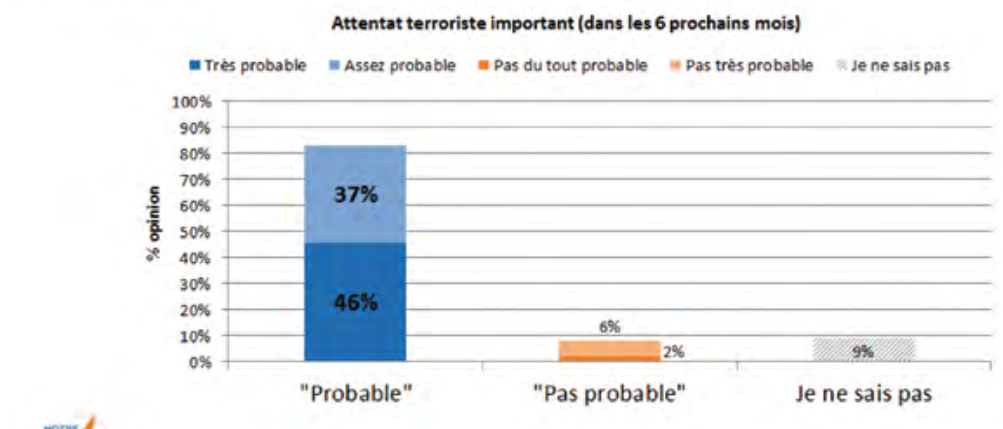

Figure 3

A never-ending crisis?

\section{FINANCIAL TURMOIL}

" How likely or unlikely do you think the following things are to happen in France? Another major financial crash in the next two years "

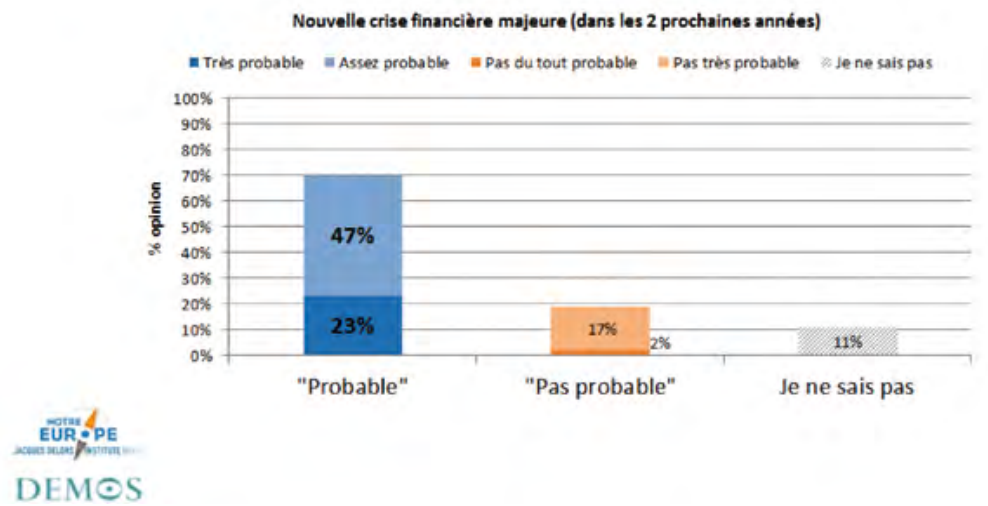

Figure 4

Cuadernos Europeos de Deusto 
iii) One of every two people in France believes that a far-right and fascist government will happen in France over the next decade. A result that seems to validate the idea that the FN has been 'normalised' and is no longer an outsider of the French political panorama (fig. 5).

\section{A never-ending crisis?}

\section{EXTREME-RIGHT}

"How likely or unlikely do you think the following things are to happen in France? A far-right or fascist political party coming to power in the next ten years "

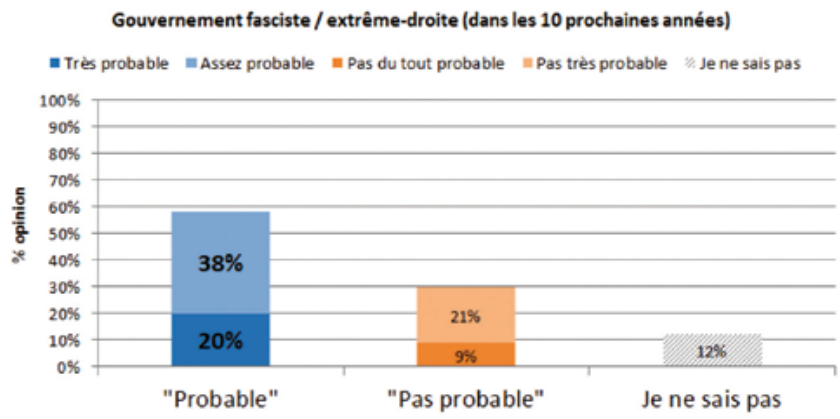

\section{Figure 5}

\section{Conclusions}

The recent electoral victory of Emmanuel Macron opens some questions regarding the fears analysed in this paper. On one hand, several studies indicate that the electoral sociology of the voters of Emmanuel Macron illustrates a fracture in the way French society confronts its fears and uncertainties. His electorate is more educated, urban, with financial means, pro-European, proglobalisation, profoundly more optimistic ${ }^{20}$. It might be argued that, consequently, his voters will not necessarily share the same approach-or the same anxiety - regarding the growing fears presented in this study.

${ }^{20}$ Ifop (2017). 
On the other hand, Macron's victory reflects two transversal trends which could be read as 'nuances' to the findings discussed here. First, pollsters commonly agree that one of the reasons behind his victory is that he managed to convince the public that he was the 'best tool' to achieve 'political change'. This might be a clear departure from the analysis we have been doing until now. Indeed, the common understanding was to say that when facing a growing will to 'change', mixed with high levels of mistrust, the result was benefiting overtly critical, authoritarian and anti-establishment parties (both on the extreme right and the hard left). The second innovation that deserves to be quoted here is that Macron was the only candidate with the same support among all age groups.

Experiences like Macron seem to confirm that our literature regarding the 'rise of fear' in Europe will probably benefit from the French assessment during the next five years. Frustration, fear, a radical will to change, might not lead systematically to extremism. Finally, I would like to quote a controversial argument made by my colleague and co-author of the report, Yves Bertoncini, former Director of Institut Jacques Delors, who likes to say that like many concepts we have abandoned positive research around the concept of 'fear'. This is a prejudice. Bertoncini likes to say that Europe should change the ode to joy to the ode to fear, in order to reveal the risks of departing from the European project. Indeed, without this capacity to consider concepts in a different light, even in academia, we will not fully understand the new political and public attitudes in Europe.

\section{References}

Alexander, Jeffrey. "Backlash Against Multiculturalism in Europe: Struggling Over the Mode of Incorporation". Conference organised by The Pears Institute for the Study of Anti-Semitism, Birkbeck University of London (2013).

Bonansinga, Donatella. "The Role of Public Discourse in Threat Framing: The Case of Islamophobia in Czech Republic", CES Working Papers, 7-4 (2015): 824-839.

Boudet, Alexandre "Les Français ne croient plus à l'état d'urgence après les attentats de Nice et Saint-Etienne du Rouvray", Huffington Post - YouGov, 4rd of August 2016, last accessed January 2018, https://www.huffingtonpost.fr/2016/08/04/etat-urgence-securite-des-francais-preoccupation-numerochomage-sondage-exclusif-yougov_n_11315414.html

Cienski, Jan. "Migrants Carry 'Parasites and Protozoa,' Warns Polish Opposition Leader", POLITICO, 14 October, 2015.

Duhamel, Alain. Pathologies Françaises. Plon, 2016.

European Commission. "Progress under the European Agenda on Migration: Press conference by Commissioner Avramopoulos", Official documentation, Ref: SPEECH/17/1626, 16 June, 2017. 
European Commission. "Rule of Law: European Commission Acts to Defend Judicial Independence in Poland", Official documentation, Ref: IP/17/5367, 20 Dec., 2017.

Gaston, Sophie. Nothing to Fear but Fear Itself, DEMOS (2017).

Furedi, Frank. Politics of Fear. London: Continuum, 2005.

Hobeika, Alexandre and Gaël Villeneuve. Les thèmes du Front National et l'agenda de la presse française (2006-2013). Counterpoint, 2014.

Ifop, "Radiographie de l'électorat d'Emmanuel Macron", Ifop survey done for the l'Obs, 5th of April 2017, last accessed January 2018, http://www.ifop. fr/?option=com_publication \& type=poll $\&$ id $=3718$

Innerarity, Daniel. "Transnational Self-determination. Resetting Self-Government in the Age of Interdependence", Journal of Common Market Studies, 53-5 (2015): 1061-1076.

Morris, Marley. "The 'reluctant radicals' who offer conditional support to the far-right are key to understanding the success of right-wing populist parties in European elections". Blog entry at EUROPP, London School of Economics, 24 ${ }^{\text {th }}$ September 2012, last accessed January 2018, http://blogs.lse.ac.uk/ europpblog/2012/09/24/europe-far-right-reluctant-radical/

Ripperger, Sabine. "Parallel Societies, Parallel Justice". Deutsche Welle, 25 th of April 2012, last accessed January 2018, http://www.dw.com/en/parallelsocieties-parallel-justice/a-15908155

Sparrow, Andrew. "Cameron Attacks 'State Multiculturalism"”. The Guardian, 26 February 2008, last accessed January 2018, https://www.theguardian.com/ politics/2008/feb/26/conservatives.race

"Terrorisme, chômage, immigration au centre des préoccupations des Français", Europe 1, 3rd of November 2016, last accessed January 2018, http:// www .europe 1 .fr/societe/terrorisme-chomage-immigration-au-centre-despreoccupations-des-francais-2890361

The Migration Observatory. "A Decade of Immigration in the British Press", The Migration Observatory at the Oxford University, $7^{\text {th }}$ of November 2016, last accessed January 2018, http://www.migrationobservatory.ox.ac.uk/resources/ reports/decade-immigration-british-press/

Wood, Claudia. "Brexit Britain Needs Big Ideas from Its Leaders, Not Tit-for-tat Politics", The Guardian, 19 $9^{\text {th }}$ of December 2017.

\section{About the author}

Dídac Gutiérrez-Peris is a lecturer at the Public Affairs School at Sciences Po Paris and works as Research Director at Viavoice, a polling institute focusing in France. He is also research associate at CIDOB with a focus on Europe. He has extensive experience in the field of European integration, in particular about opinion trends across Europe as well as postLisbon Treaty EU policy-making. Dídac holds an M.Phil from the University College London on the sociological construction of European identity, 
as well as a Master degree from the London School of Economics in Politics and Government in the European Union. He holds his Bachelor degree from Sciences Po Paris, where he specialised in Latin-America spending one year at the Institute of International Relations of the University of Brasilia. Among his most recent projects he has coordinated the French fieldwork of the multi-country study directed by the think tank in London Demos and the Institut Jacques Delors in Paris about the rising of fear in European political culture, as well as publishing several papers about French and European politics with specialised journals such as Política Exterior, Letras Libres, Beerderberg, Foreign Affairs and the European Parliament in Spain. Since 2014 he is part of the international team assisting the European Commission regarding pan-european institutional campaigns (2014-2019). He has been an op-ed columnist about European affairs for La Vanguardia (2006-2009), Passim (2009-2014) and Agenda Pública (2012-present). He contributes on a regular basis to international media such as RFI International, France24, Al Jazeera and the Clarín media group.

\section{Sobre el autor}

Dídac Gutiérrez-Peris es docente en la École d'Affaires Publiques de Sciences Po Paris y Director de investigación en el instituto de opinión Viavoice en Francia. Actualmente investigador asociado del CIDOB sobre Europa. Cuenta con una amplia experiencia sobre temas de política comunitaria, en particular sobre las tendencias de opinión en Europa y las evoluciones institucionales desde el Tratado de Lisboa. Es titular de un M.Phil por la University College London sobre política educativa e impacto de las fuentes de información en la ciudadanía. Master por la London School of Economics (LSE) sobre Política y Gobierno de la UE y por Sciences Po Paris, institución en la que también cursó su licenciatura con una especialización sobre América Latina en el Instituto de Relaciones Internacionales de la Universidad de Brasilia. Entre sus recientes proyectos se incluyen la coordinación del proyecto paneuropeo de Demos y el Institut Jacques Delors sobre los nuevos miedos en Europa, así como varios trabajos sobre política francesa y europea en revistas como Política Exterior, Letras Libras, Beerderberg, Foreign Affairs y el Parlamento Europeo en España. También forma parte del equipo asesor seleccionado para el contrato-marco de la Comisión Europea en materia de comunicación pública (2014-2019). Columnista sobre la actualidad europea en La Vanguardia (2006-2009), Passim (2009-2014) y Agenda Pública (2012-presente). Interviene regularmente en medios internacionales como RFI International, France24, Al Jazeera y el grupo Clarín. 


\section{Derechos de autor}

Los derechos de autor (para la distribución, comunicación pública, reproducción e inclusión en bases de datos de indexación y repositorios institucionales) de esta publicación (Cuadernos Europeos de Deusto, CED) pertenecen a la editorial Universidad de Deusto. El acceso al contenido digital de cualquier número de Cuadernos Europeos de Deusto es gratuito inmediatamente después de su publicación. Los trabajos podrán leerse, descargarse, copiar y difundir en cualquier medio sin fines comerciales y según lo previsto por la ley; sin la previa autorización de la Editorial (Universidad de Deusto) o el autor. Así mismo, los trabajos editados en CED pueden ser publicados con posterioridad en otros medios o revistas, siempre que el autor indique con claridad y en la primera nota a pie de página que el trabajo se publicó por primera vez en $C E D$, con indicación del número, año, páginas y DOI (si procede). Cualquier otro uso de su contenido en cualquier medio o formato, ahora conocido o desarrollado en el futuro, requiere el permiso previo por escrito del titular de los derechos de autor.

\section{Copyright}

Copyright (for distribution, public communication, reproduction and inclusion in indexation databases and institutional repositories) of this publication (Cuadernos Europeos de Deusto, CED) belongs to the publisher University of Deusto. Access to the digital content of any Issue of Cuadernos Europeos de Deusto is free upon its publication. The content can be read, downloaded, copied, and distributed freely in any medium only for non-commercial purposes and in accordance with any applicable copyright legislation, without prior permission from the copyright holder (University of Deusto) or the author. Thus, the content of $C E D$ can be subsequently published in other media or journals, as long as the author clearly indicates in the first footnote that the work was published in $C E D$ for the first time, indicating the Issue number, year, pages, and DOI (if applicable). Any other use of its content in any medium or format, now known or developed in the future, requires prior written permission of the copyright holder. 